\title{
Gendering Access to Credit: Business Legitimacy in Mandate Palestine
}

\author{
TALIA PFEFFERMAN \\ DAVID DE VRIES
}

\begin{abstract}
Although business historiography has demonstrated a variety of impediments placed on women's entry to entrepreneurship and business, the negotiated mechanisms that constructed the gendered selection has been understudied. Based on an analysis of loan applications by Jewish women in British-ruled Palestine before 1948, this article shows how material considerations to approve the loans and facilitate entry to business activity were based not merely on gender-oriented perceptions on the legitimacy of doing business, but also on a mosaic of normative constructions of family, community, and nation building.
\end{abstract}

Lotte Engel and her family arrived in Palestine from Berlin in 1938, one among many families that fled Nazi Germany. ${ }^{1}$ Prior to immigration, her husband's business provided for a comfortable living, but a few months after settling in Tel Aviv, the family became destitute. Consequently, Lotte decided to use her skills and start a business in artistic embroidery. Lacking any financial means, she was unlikely to receive a bank loan. She therefore applied for a loan from a public fund established by the Jewish Agency in Palestine to support the economic absorption of Jewish immigrants. In her application for the loan, Lotte requested 35 LP (Palestine lira,

(C) The Author 2015. Published by Cambridge University Press on behalf of the Business History Conference.

doi:10.1017/eso.2015.13

Published online April 15, 2015

Talia Pfefferman is a lecturer in the Faculty of Management at Recanati Business School at Tel Aviv University, Ramat Aviv, Israel. E-mail: taliapfe@gmail.com.

DAvid De VRIEs is a professor of history in the Department of Labor Studies, Faculty of Social Sciences at Tel Aviv University. Contact information: Naftali Building, 4th floor, Tel Aviv University, Ramat Aviv 6997801, Israel. E-mail: devries@post.tau.ac.il.

1. Loan request, 15 November, 1938. Central Zionist Archive (hereafter CZA), S7/805. 
or pounds), ${ }^{2}$ and provided the fund with two documents: an expert report stating that there was a demand for the products she designed, and a letter of recommendation from her Landsmanschaft, the German fraternal benefit association of which she was a member. Both documents specified details such as marital status, number and ages of children, husband's unemployment, and, finally, a report on Lotte's Zionist activity prior to immigration. The fund's committee decided to grant Lotte the full sum she requested, thus enabling her to establish an enterprise that, as the archived records indicate, was still thriving during the 1950s. ${ }^{3}$ Furthermore, in 1949, ten years after the establishment of her business, and upon the transition from British rule to Israeli sovereignty, Lotte, having by then gained a reputation for the quality of her work, was commissioned to embroider the Israeli national flag for the chamber of Chaim Weizmann, Israel's first president. ${ }^{4}$

Lotte's story reflects the essential role of financial credit for business in gender relations during nation building. Nation or state building is usually a transitional period in which old perceptions and attitudes coexist with the emergence of new opportunities. The enormous social and economic changes wrought by such transitions affect social mobility and gender relations. The urgency of building a national economy, in particular, opens new windows of opportunity for women-to enter business, to improve their personal economic status, to join in as contributors to the new national economy, and thus to challenge prevailing perceptions on women and gender. Acquiring credit by women for new businesses is therefore a key to materialization of these opportunities.

The historiography of the interrelations between gender and state building has largely neglected women's business and entrepreneurial activity. It focused its attention on the well-known influences of nationalism on societal perceptions of women's roles during nation and state building and on the centrality of the home economy in nation-building societies. Consequently, the wider political and cultural contexts that frame the gendering of business and entrepreneurship, and the mechanisms through which nation-building communities embed that gendering of business in society in particular, were left uncharted. The following discussion suggests that these processes are well reflected already at the entry point of women to business.

2. The association, an example of a Landsmanschaft organization based on a common place of origin, was founded on 1932 to help new immigrants. It represented the immigrants to the British authorities, assisted in finding employment and retraining, cared for families in financial distress, and provided lectures, classes, and courses in Hebrew.

3. Loan request, November 27, 1938. CZA, S7/805.

4. http://stwww.weizmann.ac.il/g-junior/weizmann-paper/17/15.html, retrieved August 17, 2013. 
Research has long recognized the gendering of business and the masculine-dominated approach to business entrepreneurship. ${ }^{5}$ The historical roots of the masculine entrepreneurial discourse are twofold. The first, the rise of modern capitalism, enhanced the differentiation between technological innovations and industrialization and that between the living space and the workplace. The differentiation was buttressed by a second process, the rise of the middle class, which extolled a division of activities into private and public spheres. In this middle-class discourse, men's territory was the public, and the economic individual was perceived as an autonomous, rational man. Terms such as "work," "wages," and "career" rendered engagement in economic activity masculine. ${ }^{6}$ Women were confined to the private sphere, to housekeeping and to caregiving labor. Herein lay the roots of the essentialist perceptions of women as emotional, irrational, and impulsive and, therefore, as naturally unsuited for independent economic activity as businesswomen. ${ }^{7}$

This did not mean that, despite many impeding forces, women did not become entrepreneurs. Their business activity, whether operating from within the home or outside it, blurred the cultural distinction between the private and public spheres. ${ }^{8}$ Nevertheless, entrepreneurial activity was still divided by gender. Most women were absorbed in the services sector, in female-associated occupations in particularfashion (millinery, sewing), cosmetics, and hoteliery-based, as they were, on knowledge attained from a variety of home chores-feeding, sewing, and reception of guests. ${ }^{9}$ Women's enterprises also tended to operate in smaller volumes than men's, evidently hampering the attainment of financial credit. ${ }^{10}$

5. Brouwer, "Schumpeter and Knight on Entrepreneurship and Economic Development." Note also that Schumpeter's notion of creative destruction was largely borrowed from Werner Sombart, whose influence on Zionist economic thought is well recognized. See Penslar, Shylock's Children, 163-166; Cuevas, "Towards a Taxonomy of Entrepreneurial Theories"; Gamber, "A Gendered Enterprise”; Peiss, "Vital Industry”; Scott, "Conceptualizing Gender.”

6. For the middle-class notion of gender and business, see Davidoff, "Gender and the 'Great Divide"'; Davidoff and Hall, Family Fortune; Simonton, A History of European Women's Work; Ryan, Cradle of the Middle Class.

7. Gamber, "A Gendered Enterprise"; Kwolek-Folland, Incorporating Women; Rutterford and Maltby, "The Widow, the Clergyman and the Reckless"; Walsh, "Gendered Endeavors."

8. Ingalls Lewis, Unexceptional Women; Kerber, "Separate Sphere, Female Worlds"; Landes, "Further Thoughts”; Vickery, "Golden Age to Separate Spheres?”; Phillips, Women in Business.

9. Gamber, “A Precarious Independence”; Nenadic, "The Social Shaping of Business"; Peiss, "Vital Industry”; Sharpe, "Gender in the Economy”; Sparks, Capital Intentions.

10. Ericsson, "Women, Family, and Small Business"; Ingalls Lewis, Unexceptional Women; Phillips, Women in Business; Walsh, "Gendered Endeavors”; Yohn, "Crippled Capitalists." 
Moreover, unlike that of men, women's entrepreneurship was immersed in the family. Whereas married women were active mainly within the framework of the "firm of husband and wife," operating as "deputy husbands," unmarried women, divorcées, and widows turned to business because of the absence of a breadwinner. Among the latter, family members and close relatives intervened in the daily running of the women's business, and, though often resented, they influenced business decisions and financial management to the point of sometimes even harming the business. ${ }^{11}$

Although ample research demonstrates the expansion of women's entrepreneurship and the consequent need to problematize the separateness of spheres, its cultural influence on business acumen should not be taken lightly. The cultural association between women and the home-which the separate-sphere paradigm, in fact, cultivatedturned women's respectability into a crucial factor in defining the legitimacy of women's business in general, and in attaining financial backing and credit. ${ }^{12}$ This was the case, for example, in the emphasis by women entrepreneurs on the familial or domestic aspects of their actions, in which the private-public distinctions were blurred. In the fashion trades, women proprietors often cared to give their salons a hospitable and domestic-like atmosphere. Moreover, whereas businessmen declared the purpose of their enterprises to be the generation of profits and accumulation of capital, businesswomen publicly justified their activity by referring to its contribution to better housekeeping among other women, thus placing the logic of their activity in the framework of the greater good of the community. ${ }^{13}$

Similarly, the literature on gender and nationalism has long demonstrated the inherent gendered discourses of national movements. ${ }^{14}$ In addressing women's participation in national struggles, it emphasized, first and foremost, the symbolic aspect: women's association with the soil that needed to be defended and with nation's motherhood-child rearing and national-oriented education of the young. ${ }^{15}$ That discourse emphasized no less the role of women as

11. Beachy, "Business Was a Family Affair"; Ericsson, "Women, Family, and Small Business"; Gamber, “A Precarious Independence”; Kwolek-Folland, "Vital Industry"; Nenadic, "The Social Shaping of Business"; Sparks, Capital Intentions.

12. Gamber, "Gendered Concern."

13. Nenadis, "The Social Shaping of Business"; Yohn, "Crippled Capitalists."

14. Abdo, "Nationalism and Feminism" (Abdo refers to nationalism as "doubleedged” regarding women [p. 150]); Nagel, "Masculinity and Nationalism”; Nairn, The Breakup of Britain; Silva, The Gendered Nation; Yuval-Davis and Anthias, Women, Nation, State.

15. Delaney, "Father State, Motherland"; Maleckova, "Where Are Women in National Histories?”; Mayer, "Gender Ironies of Nationalism”; Moghadan, Gender and National Identity; Nagel, "Masculinity and Nationalism." 
active combatants, military nurses, intelligence operators, leaders of civilian action against foreign and colonial rule, organizers of patriotic associations to support soldiers and the military campaigns of governments and states, and as participants in cultivating the consumption of nationally associated products and the boycotting of others. ${ }^{16}$ The latter was naturally associated with the national imperative of rationalized and calculated running of the home economy, and with the turning of the woman homemaker into a participant in fulfilling the nation's needs. ${ }^{17}$

The conceptual framework that these historical and cultural treatments of gender, business, and nationalism provide has not, however, been applied in the case of the gendering of entrepreneurship and business in nation-building processes. Practically, a historically expanding group of women whose entrance to business was either affected by these highly political and cultural processes, or who meant to recruit these processes to their own interests and advancement, was largely ignored. In the following, we focus on such a group of women in the Jewish community in the Palestine Mandate under British rule (the Yishuv), and in particular on their entry point to business. At this point, myriad negotiations had taken place between women wishing to enter business and committees (mostly run by men) who were supposed to grant them loans.

The discursive richness of these negotiations reaffirms the significance of credits and loans as mediators between individual activity and broader economic processes as they facilitate the overcoming of the dearth of private resources for any entrepreneur-and women in particular. Moreover, because the negotiations touched on delicate questions of kinship and social networks and of mutual trust, they turned into a site in which the identity of the women as businesswomen was shaped, and in which the business-gendering mechanisms of the nation-building community were exposed. ${ }^{18}$

As a national ideology, Zionism meant first the transformation of the Jews into a nation. Second, it oriented itself on the establishment of a national polity in Palestine and creating a state. ${ }^{19}$ In practice, this meant relocating a large part of the nation-to-be and its concentration in Palestine in order to form a modern, sovereign, and

16. Silva, The Gendered Nation, 28-29; Hegland, "Gender and Religion in the Middle East and South Asia”; Aretxaga, Shattering Silence; Jayawardena, Feminism and Nationalism; Fleischman, "The Other Awakening."

17. Reagin, "The Imagined Hausfrau"; Sweeping the German Nation.

18. Muldrew, "Interpreting the Market"; Sharpe, "Gender in the Economy." For an overview of women and credit, see Lemire, Pearson, and Campbell, Women and Credit.

19. Horowitz and Lissak, Trouble in Utopia, ch. 3; Kimmerling, "State Building." 
independent state. The case of the Zionist community in Mandate Palestine is relevant to the research on women entrepreneurs for two reasons: first, because of the widely held perception in Yishuv society of nation building as closely associated with social change, partly with regard to gender relations; second, because business and entrepreneurial activity in Yishuv society was central to the economic viability of the Yishuv vis-à-vis the Arabs, and therefore to the attainment of political independence and future statehood. ${ }^{20}$

From 1918 to 1948, Palestine was under British rule. As a Crown colony, under a mandate given to Britain by the League of Nations, the country was administered by the Palestine government. The government-for all practical purposes, an emissary of the Colonial Office in London-ran an economic policy that catered to Britain's imperial interests in the region. The latter dictated a low-cost administration of Palestine and therefore a noninterventionist policy with minimal contribution to the country's financial infrastructure. ${ }^{21}$ The Arab and Jewish communities in Palestine ran their institutions and social affairs separately. ${ }^{22}$

Prior to the British occupation of Palestine in 1917-18, the Palestine economy was based mainly on agriculture and smallscale manufacturing. Following the British occupation, the local economy took its first steps toward the development of modern industries beside a growing service sector. ${ }^{23}$ The Jewish community during the mandate period grew mainly through immigration. Political and economic hardships in eastern and central Europe, as well as emerging Zionist notions or immigration quotas in Western countries, drove Jews to immigrate to Palestine. Although the arrival of immigrants and the accompanied import of capital contributed to the development of certain economic branches and industries and increased consumption, the small emerging local economy struggled to absorb the newcomers and failed to provide channels of salaried employment. As a result, many immigrants who lacked means of subsistence turned to entrepreneurship and tremendously increased the demand for credit and loans. Though typically leaning on low-interest credit resources provided by immigrant fraternal and

20. For links between private entrepreneurial activities and the growth and invigoration of national economies, see Kocka, Industrial Culture and Bourgeois Society.

21. Metzer, The Divided Economy.

22. The absence of parallel primary sources on business loans among Arab urban residents dictated the focusing of our discussion on the Jewish community. For the Arab rural sector, see Nadan, "The Competitive Advantage."

23. Gross and Metzer, "Public Finance in the Jewish Economy"; Metzer, The Divided Economy. 
benevolent organizations, the demand also pressed for a publicinstitutional response. ${ }^{24}$

Against this background, the Zionist movement-and the Jewish Agency, which ran the affairs of the country's Jewish minoritycultivated autonomous financial institutions that catered for banking and financial services. Private enterprises were one of the main institutional forces that sought to administer Jewish immigration and the importation into Palestine of Jewish capital. As a strategy in the national conflict with the Arabs of Palestine, private enterprises were therefore destined to buttress an autonomous economic sector within Palestine's economy. ${ }^{25}$ For this purpose, the Jewish Agency, together with various business associations and small-scale private banks, initiated the establishment of loan funds.

As the Zionist movement perceived economic autonomy to be an essential means in the Zionist nation-building process, politics and economics were deemed inseparable. This was why Yishuv institutions and the communal infrastructure they created aimed to deal with many aspects of civilian life-from consumption to child rearing, and, relevant to our discussion here, with personal and collective economic and entrepreneurial opportunities. This was highly relevant for Jewish women who, as immigrants and Yishuv members, depended on both familial and public resources for their personal advancement.

The Zionist movement hardly presented a consistent approach to women's agency. Similar to those in other national movements, many of the Zionist thinkers identified Zionist nationalism with manly physical power, and accorded women the traditional roles of giving birth, child rearing, and education. ${ }^{26}$ However, the writings of Theodor Herzl, the founder of Zionism, clearly explicated the quest for gender equality, and in 1899 the Zionist Congress granted women to right to vote and be elected. ${ }^{27}$ The ambivalence was also cross-class, as demonstrated by the dual approach of the labor movement, the rising political power in the Yishuv, and the Zionist movement in the 1930s: espousing gender equality among workers, yet discriminating against women in job allocation; advancing the formative role of women in the working-class family on the one hand and relegating them to traditional home chores on the other. ${ }^{28}$ Hence, the circumstances that molded the opportunities for women striving to enter

24. For the relations between immigration and entrepreneurship, see Godley, Jewish Immigrant Entrepreneurship.

25. Eilam, The Jewish Agency.

26. Gluzman, The Zionist Body; Hyman, Gender and Assimilation.

27. Gluzman, The Zionist Body; Herzl, Altneuland.

28. Bernstein, "The Ploughwoman"; Pioneers and Homemakers; Stern, "He Walked Through the Fields." 
entrepreneurship emanated from social aspirations for equality, for national sovereignty, and from cultural gender perceptions.

Our discussion is based on two sources. One is documents produced in the process of application for business loans from Zionist public funds, found at the Central Zionist Archive in Jerusalem (CZA). Some 2,000 loans granted from 1938 to 1941 were retrieved. Each document contains the amount of the loan, the name of the business owner, and the business sector. In addition, we located 420 protocols of the loan committees' minutes. Each protocol contains the actual application, information on the applicant, the recommenders and the guarantors, summaries of the committees' deliberations, and their final decisions. We concentrate in this article on the minutes of the committees in the three largest urban business centers: Tel Aviv, Haifa, and Jerusalem, where the Jewish middle class was formed.

The second source on which the discussion is based is the correspondence produced by 185 certification processes of women-owned businesses in Tel Aviv and Jaffa from 1937 to 1945, found in the historical archive of the Municipality of Tel Aviv-Jaffa (MATEJ). ${ }^{29}$ The files contain the exchanges between the women applicants and the town's functionaries and among the latter themselves. The advantage of this source is in providing a local perspective that complements the information gleaned from the national-level source. For a wider perspective on contemporary debating on economic issues, we also scanned the contemporary press and bulletins of commercial associations.

The mix of quantitative and qualitative materials gave us a reliable picture of the gendering of business during the British Mandate period-the formative nation-building period. They provide information not only on the language and content of the justification discourse brought forth by women's loan applications, but also on the response of the institutions. In effect, they expose the negotiations between the applicants and the financial bureaucracy on the opening of businesses by women, and their respective arguments for one side or the other.

Although it is not clear how many women managed to enter business and what was the occupational breakdown of those who succeeded in maintaining a business, the data demonstrate that similar to women in other countries, most businesswomen were absorbed in the services sector. This is shown in Table 1. Moreover, many of the businesses they started were closely related to the home economy. Women business owners in the three large towns-Tel Aviv-Jaffa,

29. Regarding the issues under discussion here, there is no distinction between the negotiations over loans and over licenses; therefore, they are discussed here as one undifferentiated repository. 
Table 1 Main branches of women's businesses in urban centers in 1930s Palestine

\begin{tabular}{lll}
\hline Branch & Town (Year) & Women Owners (\%) \\
\hline Guest houses & Tel Aviv (1933) & 65 \\
Hotels & Tel Aviv (1933) & 16 \\
Cafés & Tel Aviv (1933) & 23 \\
Textile retail & Tel Aviv (1937) & 32.3 \\
Textile retail & Jerusalem (1937) & 43.3 \\
Textile retail & Haifa (1937) & 42.7 \\
Textile manufacturing & Tel Aviv (1937) & 50 \\
Textile manufacturing & Jerusalem (1937) & 44.8 \\
Textile manufacturing & Haifa (1937) & 47.6 \\
Restaurants & Tel Aviv (1939) & 18.4
\end{tabular}

Source: CZA S18/261, 262 and 263; MATEJ 04-3076, 04-2314.

Haifa, and Jerusalem-were active mostly in food, textiles, and hoteliery, and were remunerated mostly at home. A sampling of the 1937 census of the Jewish population of Jerusalem revealed that of 516 women, 36 ( 7 percent) were self-employed and that half of them (18) operated their businesses in the space of their homes. A decade later, a report written for the Women's International Zionist Organization (WIZO) in 1948 disclosed 4,000 women who operated in this home-economy framework-in sewing, weaving, baking, cooking, ironing, and overnight hosting. ${ }^{30}$ The list of loans given to women for starting a business corroborates the occupational distribution. As demonstrated in Table 2, the loans given were indeed modest. However, given the overall volume of economic activity in Mandate Palestine and the primacy of small and medium-sized businesses, the loans were significant for renting a space and for purchasing the basic equipment for the business. Women's business loan applications were therefore crucial for entering business and for the initial economic viability of the businesses.

\section{In Search of Legitimacy}

For many Jewish women who immigrated to Palestine in the interwar period, the varieties of business activity were well known. In Eastern Europe, women in religious families whose husbands immersed themselves in religious learning were the principal breadwinners. ${ }^{31}$

30. Turnowsky-Pinner, Jewish Women of Palestine. For the small volume of activity of women's businesses and their affiliation with domestic work, see Ingalls Lewis, Unexceptional Women; Sparks, Capital Intentions.

31. Burman, "The Jewish Woman as Breadwinner"; Zborowski and Herzog, Life Is with People. 
Table 2 Allocation of business loans to women, by branch of business, in 1930s-1940s Palestine

\begin{tabular}{llll}
\hline Branch & Town & $\begin{array}{l}\text { Average } \\
\text { Loans (LP) }\end{array}$ & $\begin{array}{l}\text { Percentage of } \\
\text { Women Recipients }\end{array}$ \\
\hline Greengrocers & Tel Aviv & 23 & 15 \\
Grocers & Tel Aviv & 47 & 10.7 \\
Petty traders and craftspeople & Tel Aviv & 23 & 15 \\
Peddlers and kiosk owners & Tel Aviv & 26 & 13.1 \\
Petty traders & Haifa & 30 & 7.2 \\
Petty traders and craftspeople & Jerusalem & 33 & 6.5 \\
\hline
\end{tabular}

Source: CZA S 18/34 and 213.

In both secular and religious low-class families, women engaged in trade and manufacturing businesses-in particular, in sewing and small-scale production of textiles. ${ }^{32}$ Class in central Europe was no less influential in determining the involvement of women in business. In Germany, for example, middle-class norms of respectability and women's attachment to the family and the home economy impeded women's cultivation of business independence. ${ }^{33}$ In comparison to Christian women, however, many of these Jewish businesswomen served as helpers at family shops and assisted in running family businesses. Moreover, Ostjuden women-low-class Jewish women who emigrated from Galicia to Germany—ran small businesses such as hostels, restaurants, and peddling. ${ }^{34}$ It was no wonder, therefore, that in Palestine they would often continue the same sort of business activity.

Other Jewish immigrant women who grew up in the central European bourgeois atmosphere, and never worked, were hard pressed to establish a business in Palestine as a result of the dwindling of the family's resources or of the loss of their spouses and their breadwinning capacity. ${ }^{35}$ Among these were women who acquired new occupations or simply reproduced in Palestine a skill they learned beforehand. ${ }^{36}$ A survey conducted by WIZO on the occupational distribution of German immigrants to Palestine demonstrated that the majority originated in the professional middle class. Among 179 women who found work, 169 changed occupations; a third of them were unmarried women who had never worked before. Many of these started working as janitors, low-skilled textile workers, and meal preparers at their lodgings. Only few could make a deeper career

32. Glenn, Daughters of the Shtetl; Green, "Gender and Jobs"; Hyman, Gender and Assimilation.

33. Hausen, "Family and Role Division"; Kaplan, "The Making of the Jewish Middle Class.”

34. Green, "Gender and Jobs"; Kaplan, The Making of the Jewish Middle Class.

35. Loan request, November 27, 1938. CZA, S7/805.

36. Pfefferman, "Separate Spheres, Intertwined Spheres." 
change, as the survey explained: "One singer opened a millinery shop and one actress a hairdressing salon.... Only one academic-formerly a court secretary-turned to manufacture, that is, to self-employed book binding." 37 Therefore, women changed occupations according to the mix of previous skills and the demand they identified in their new location. The survey added that occupational change was often associated with a decline in standards of living compared with those in the country of origin. However, as social stratification and class distinctions in the Yishuv were less clear cut, and as many immigrants shared similar material decline, it did not necessarily mean a drastic social decline. Individual status in the Yishuv was often determined by having had a prestigious occupation or public status in the country of origin.

The turn of women in the Yishuv to small-scale business and to a variety of entrepreneurial activities was partly a corollary of the disruption caused by immigration-in particular, the detachment from long-established familial and economic ties. However, women's dire economic condition in the immediate post-immigration years, the competition with men, and the paucity of banking and credit institutions in Palestine caused the high dependence of the women on credit funds created by the Yishuv and Zionist institutions. Moreover, women who sought to open businesses faced the dual challenge of recruiting seed capital and of facing negative institutional perceptions regarding business and gender. These perceptions originated both in lower-middle and middle-class norms in Eastern and Western Europe regarding the private and public spheres, and in the primacy accorded by the Zionist elite to nation building. Consequently, women who both wished to legitimate their business plans and perceived themselves as committed Zionists and members of the Yishuv community cultivated a complex strategy. Although they complied with the perceptions that impeded their advance- - their attachment to the home and the family and their essential role as women in nation building-they also sought to manipulate these precepts to justify their quest for business loans.

High-level literacy was one of the aspects of the self-selection that shaped the social structure of Jewish women immigrants to Mandate Palestine. This was exemplified by the fact that most of the petitioning for loans and written exchanges between the applicants and the loan institutions over the authorization to run a business were written by the women themselves. ${ }^{38}$ The ability of women immigrants-mostly

37. Brichni-Schimmer, "The Professions of Immigrants from Germany."

38. For example: Regina Perlmuter to Tel Aviv Municipality, license application, December 1, 1939, MATEJ, 04- 2357; Rebecca Hiefetz to Tel Aviv Municipality, license application, February, 7, 1939, ibid.; Ester Rievis to the German department of the Jewish Agency, April, 29, 1943, CZA, S7/2121 
versed in German, Polish, Russian, and Yiddish-to write and negotiate in Hebrew freed them from the need to be represented by others. Furthermore, it exhibited to the institutional lenders the sense of the women's independence that was so imperative for running a self-owned business.

At the same time, however, the language of loan request letters disclosed the partial character of that independence. Letters by men focused on the nature of the venture and detailed its financial requirements, such as in the case of a hotel owner applying for a loan: "I am a hotel owner in Jerusalem, my business develops well thank God and there is hope that in due course it could provide my living and with profit; but to improve it and make it stand on a solid base I need to invest a proper sum. ... That is why I turn to you to authorize me a comfortable loan in the sum of LP 25 of your loans fund. The two guarantors to provide me the guarantee are..."39 Another businessman, in pursuit of a business license, took the following straightforward approach: "I wish to set an appointment with Mr. Dr. Bernstein in the matter of accepting the assistance of the [Jewish] Agency to establish large scale home industry of local original embroidery for exportation to the United States. My partner is in the United States for two and a half months now negotiating with relevant important establishments." 40 Conversely, women petitioners did not apply such a direct businesslike manner in their applications. Conscious of accepted social classifications concerning middle-class women's domestic duties, many of those wishing to become entrepreneurs attempted to obfuscate the perceived transgression by emphasizing their familial conditions as causes that drove them to consider undertaking a business. This was why many women-in contrast to menwould begin their applications by detailing their status as wives, mothers, or single women, emphasizing in particular some familial malfunctioning. One reason women advanced was immigration: "It is three months since I immigrated to Palestine to join my husband who had been unemployed for a long time. ... Here I am destitute." 41 Others extensively described the family's tribulations following immigration, such as in this typical letter: "Not only has my husband been long unemployed, but he also recently fell ill and was almost struck with a disease of the nerves. He leaves home for weeks and

39. Malkiel Grinwald to the department of small trade at the Jewish Agency, April 27, 1939, CZA, S18/60.

40. Issack Shpringer to the department of trade at the Jewish Agency, no date, CZA, S8/700.

41. Regina Perlmuter to Tel Aviv Municipality, license application, December 1, 1939, MATEJ, 04- 2357. 
nothing is known of his whereabouts." 42 Other women detailed the circumstances of widowhood in new surroundings away from old communal networks: "Two months ago my husband died and I am left alone, starving to death. I have no children, nor brother or sister who could assist me, I am entirely alone." 43 A number of women noted the desertion that often occurred through the immigration process: "I am alone and deserted. ... I have to provide for myself and my two daughters. I have assistance and support from no one and all the burden falls on my shoulders." 44

The wording of the applications demonstrates the extent to which women reiterated the traditional familial model in which the male is the main breadwinner, and used that model for advancing their business strategy. The absence of a man-due to either incapacitation or death-was cited to justify their business claims. The feminine passivity they expressed enhanced the imploring implied by the initial turn to a manly authority to solve a problem. Applicants made use of the prevailing norms to affiliate with the business world.

Moreover, in addition to detailing familial circumstances, in some cases women would draw a direct affiliation between their business endeavor and their spouse (alive or dead). Although the applications might specify the women as sole owners, many women nonetheless noted their husband's name and occupation or his affiliation with the new business in their request, as in the following: "I am a widow, my husband left a plot of land for me to build a shop on." ${ }^{45}$ In the applications to the committees, the "wife of" or "widow of" are recurring terms. An applicant for entry to entrepreneurship was often represented not as an individual striving to become an entrepreneur, but rather as someone following the execution of the will and aspirations of the deceased husband: "I would like to mention that owning a soda parlor was a constant desire of my late husband." 46 The common reference of women applicants to their husbands is in stark contrast to the absence of any information concerning the family or spouse in similar applications by men.

42. Ahuva Ziedenberg to Tel Aviv Municipality, license application, May 22, 1938, MATEJ, 04-2357.

43. Rebecca Heffetz to Tel Aviv Municipality, license application, February 7, 1939, MATEJ, 04-2357.

44. Judith Rosenberg to Tel Aviv Municipality, license application, January 31, 1941, MATEJ, 04-2281.

45. Tova Aptieker to Tel Aviv Municipality, license application, March 17, 1939, MATEJ 04-2357.

46. Rachel Karo to Tel Aviv Municipality, license application, May 1, 1938, MATEJ, 04-2357. For a similar tactic in other locations, see Wood, "Broken Reeds and Competent Farmers." 
Institutional intervention was a key factor in encouraging the association among women's business, the home, and the family. In 1939, WIZO collaborated with the Jewish Agency-the organization that, since 1929, served as the main representative and organization of the Jews in Palestine-in establishing a system of women's home industries. ${ }^{47}$ The project, inspired by similar projects previously developed in Europe, created funds to finance both the acquisition of skills and the purchase of equipment and raw materials-in particular, in embroidery, hand weaving, toy making, and costume jewelry. ${ }^{48}$ The project advanced the notions that women could be brought to become self-earning, and support their families, mainly though working at home, and the interlacing of women's independent labor with the home economy. Moreover, women who applied for loans for business outside the home, and used WIZO recommendation letters to soften opposition to their entrepreneurial drive, indirectly reproduced the institutional assumption regarding the primacy of the home as women's main business arena.

Notwithstanding, while justification to enter entrepreneurship rested for many women within the home and familial circumstances, the Zionist priority of state building was just as dominant in dictating the rhetoric and practice of women entrepreneurs. Immersed in nation building and national conflict, the Jewish community in Palestine aspired to economic independence. Among the entrepreneurs, industrialists, and businesspeople, many espoused "national capitalism"-the intertwining of doing business for profit with investment for the social good and the attainment of Zionist goals: Jewish immigration to Palestine, settlement in autonomous Jewish communities, and the establishment of a Jewish sovereign state. ${ }^{49}$ Women entering entrepreneurship aspired to participate in the national economy-building process as a possible channel for gaining legitimacy.

This national capitalism was expressed by Shoshana Persitz (1893-1969), who founded the Omanut art printing and publishing house in Moscow in 1917. Seeking funds to reestablish her venture in Palestine in the early 1930s, Mrs. Persitz wrote: "Among the few who first took the initiative to bridge through private enterprise the hiatus left open by national [Zionist] endeavor were the founders of the 'Omanut Publishing Company.' ... Its aims were: (a) to promote the

47. "Developing Home Industries," a report, CZA, S1/2036, 1943, no date; Protocol Concerning the Society for the Development of Home Industries LTD, September 2, 1947, ibid., S8/700.

48. Home Industries report, no date, CZA, S80/700; meeting protocol, the Foundation of Home Industries, ibid., S1/2036, September 11, 1944.

49. For a similar strategy among Jewish white-collar professionals, see De Vries, "National Construction of Occupational Identity." 
revival of the Hebrew language and scholarship; (b) to prepare the way for a sound Hebrew book industry in Palestine, worthy of the 'people of the Book'.,"50

Beekeeper Betty Zaft employed similar language. In her loan application, she emphasized her credit as a "veteran Zionist," adding an exclamation mark. ${ }^{51}$ In another letter, Zaft noted that the honey she produced and exported from Palestine highlighted its origin on the jar labels: Eretz-Israel honey (from the land of Israel). ${ }^{52}$ These specific references in two different documents demonstrate that Zaft was well aware that linking her private business with the Zionist vocabulary of national revival would facilitate obtaining her loan.

This linguistic formulation was hardly exclusive to women. In the first half of the twentieth century men, too, would employ the association of business with Zionism to gain legitimacy for their private ventures. Women's justification projects, however, were distinct in their twofold sophistication. On the one hand, they advanced their commitment to the business community, which sought to present itself as a productive force in the nation-building project. On the other hand, they justified their transgression and deviation from the traditional national roles allocated to women-as mothers and wives-by associating their business activity with the national cause. Advancing mere economic independence would otherwise have been considered a breach of socially accepted gender roles, which were upheld widely by various political and social leaders of the Yishuv and by the contemporary press.

Moreover, the adherence of women who sought to be active in business to national capitalism-that is, to mixing the search for profit with Zionist collective purposes-served to legitimate their entrepreneurship, but also to harness nation building to developing the business itself. Shoshana Persitz, for example, focused most of her publishing on learning and educational books in Hebrew, the high demand for which was created by a Zionist-oriented schooling system deeply committed to cultivating modern Hebrew among the young. These reciprocal relations between a business opportunity in commercial publishing and service to nation building were further accentuated in another example of the Tel Aviv-based woman publisher Bracha Peli (1892-1986), who also prided herself in commitment to Hebrew as culturally instrumental in the materialization of

50. Memorandum, 1933, no date, CZA, L246/51, p. 2. For the mixing of Hebrew with other languages in commercial activities, see Halperin, "Babel in Zion."

51. Betty Zaft, loan application, July 2, 1945, CZA, S7/2170.

52. Betty Zaft to Arthur Ruppin regarding her loan request, May 26, 1937, CZA, S7/2170. 
Zionism in Palestine. ${ }^{53}$ Evidently, Zionist allusions in business practices that aimed to enhance legitimacy in the Yishuv community were well received, as demonstrated by Lotte Engel's case that opened this article. Furthermore, professing a Zionist approach to Arabs was an essential part of that legitimating capitalist-national rhetoric. For example, during the Arab rebellion and the Arab boycott on selling materials to Jews in the mid-1930s, Elisheva Porter, the owner of a thread-spinning workshop in Tel Aviv, diverted to purchasing the materials from Arabs to Jews and replaced her Arab girl employees with Jewish ones. In her business loan requests, she argued that both moves raised the demand for her products in the Yishuv, in addition to the "Hebrew labor only" signature she imprinted on them. ${ }^{54}$ The exclusion of Arab women workers clearly demonstrated the gendered aspect of the national divide that Porter willingly propagated. Unsurprisingly, in the early 1940s she turned into one of WIZO's main suppliers of spun threads for the home-industry project it ran for women, and indirectly became an active participant in absorbing Jewish immigrants. ${ }^{55}$ After all, in the wake of the Arab rebellion, the latter was considered a national imperative.

The mixing of personal and business legitimization through nationalism could materialize in unexpected channels in which, on rare occasions, national imperatives were challenged by women in the course of business negotiations. A number of women who applied for business licenses tried to advance their cases by challenging the preferences dictated by adherence to the Zionist cause. One example was the threat made by a woman applicant that economic hardship might impel her to send her children to a Christian boarding school, as these schools were willing to admit children at no charge. ${ }^{56}$ The threat was both national and social. Handing over children to the Christian mission posed a demographic threat and reproduced deep, historically based fears of Jewish assimilation in the Diaspora. At the same time, giving the children away meant relinquishing the assigned role allocated by Zionism to women as familial guardians and bearers of cherished Zionist tenets. Such threats were taken seriously in a society in which nation building was a prime symbolic resource, and it was therefore "natural" for the municipal clerks to add a cautionary note to the applications calling for reconsideration.

53. Peli, Life of Bracha.

54. Porter to the Department of Trade and Commerce at the Jewish Agency, CZA, S8/1706, October 15, 1936.

55. "The Wool Exhibition in Jerusalem," Davar (Histadrut's daily paper), March 11, 1941.

56. The committee for preventing foreign education to Tel Aviv's Deputy Mayor regarding a business license for Tova Gertenloyb, August 3, 1939, MATEJ, 04-2273. 
Scrutinizing women's tactics reveals a common use of home and family and of nation building to justify and legitimate their entering into entrepreneurship (see Figure 1). Whereas the former was presented as a push factor based on life's necessities, the latter presented the ambition to contribute to the national greater good while simultaneously being employed to promote the legitimacy and performance of the business itself.

\section{Facing the Committees}

The long-standing tradition of credit and loan institutions in the Diaspora and their paucity in Palestine were behind the decision to create such institutions under the auspices of the Zionist movement and the Yishuv. ${ }^{57}$ These, it was thought, would attract Jewish capital owners to Palestine and buttress the mix of capital investment and Zionist nation-building purposes. ${ }^{58}$ In parallel, under the pressure

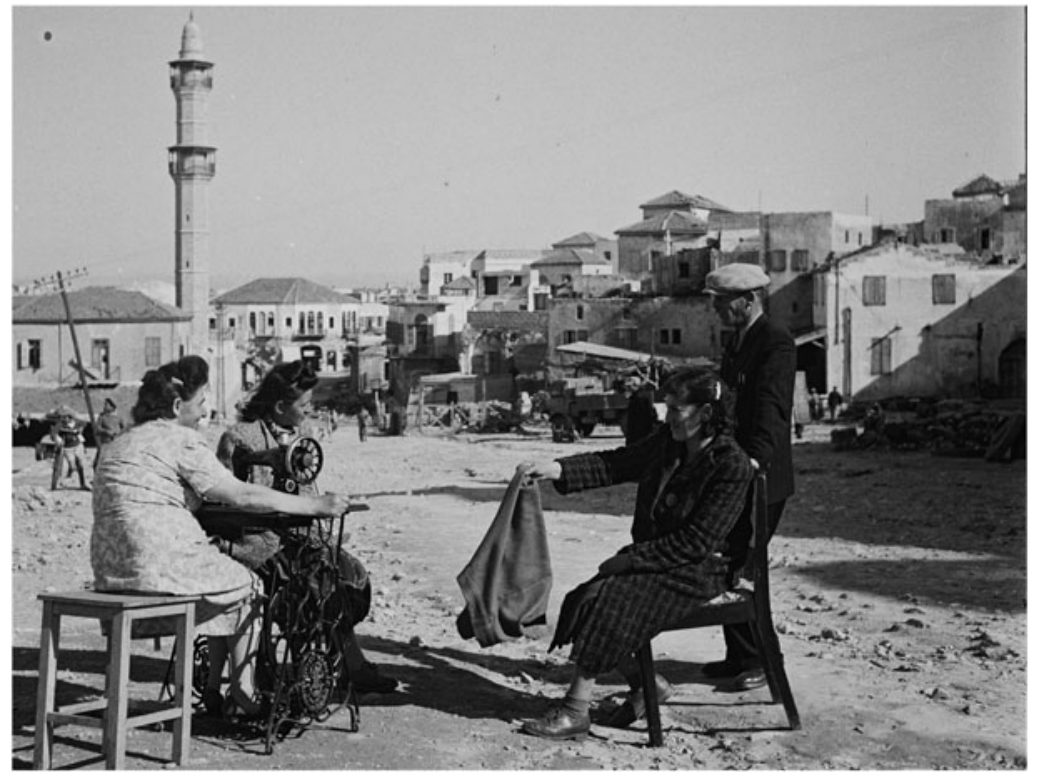

Figure 1 A Jewish immigrant from Bulgaria working on her sewing machine in postwar Jaffa (Israel), October 1, 1949. Photographer: Zoltan Kluger. Courtesy of The State of Israel: National Photo Collection.

57. Joffe, "The Dynamics of Benefice"; Lestchinsky, "Economic Aspects of Jewish Community"; Tenenbaum, "Culture and Context." This model was adopted by Jewish immigrants in other locations in the West; see, for example, Godley, "Jewish Soft Loan Societies"; Taschereau, "Jewish Loan Societies in Montreal."

58. Metzer, "Economic Structure and National Goal." 
of Jewish small-scale capital owners in Palestine, a series of private credit boards were established by middle-class associations. These catered, in both the rural and urban areas, to the financial needs of their members and for advancement of their business schemes. Urban middle-class formation in Palestine's Jewish polity could not be understood without the preferential treatment they provided, particularly in the three major social concentrations in Tel Aviv, Haifa, and Jerusalem. ${ }^{59}$

The variety of public and private loan organs (Jewish Agency backed, private middle-class associations, and traders' and manufacturers' organizations) promised that the absence of similar British-backed instruments would not impede Jewish business activity. ${ }^{60}$ Loans were granted for various lengths of time for their return, most commonly twenty-four months, and the interest was mostly bearable and resembling charity funds. ${ }^{61}$ Loan takers needed guarantors and signed guarantees for the return of the loans, or they could mortgage personal property and machines. ${ }^{62}$ Follow-up lists of repayment were conducted and, should a borrower fall behind because of various hardships, the loan terms and installments were often accommodated accordingly. ${ }^{63}$

Around these operations developed both a complicated bureaucracy and a web of social networks that provided recommendation letters and sources of follow-up information on the clients. Moreover, as the Palestine government was not involved in these financial systems, they lacked deterring or enforcing powers. ${ }^{64}$ They depended therefore mostly on trust, on the information that could be culled from immediate relatives and wider social networks, and on a normative classification of the credibility and worth of those who were given the business loans. In these classifications, notions of nation building and of roles in Zionist practices were often influential. Moreover, the dependence on the loan funds of any who sought to enter business

59. Alroy, "The Craftsmen"; Karlinsky, "Private Credit Cooperatives."

60. List of institutions participating in various loan funds founded by the department of craft and small trade in the Jewish Agency, May 1, 1938-August 1, 1939, CZA, S18/213. The list contains funds of the Jewish Agency, private loan cooperation, Anglo-Palestine Bank, and the like.

61. "A" fund for small traders and craftsmen, 1939, CZA, S18/105; middle class and saving funds loans for traders and craftsmen, September 30, 1940, ibid., S18/34.

62. Loan applications, CZA, S21/221; loan and credit fund for craftsmen, Protocol 95, November 21, 1939, ibid., S1/1886; protocol 107, January 14, 1940, ibid.

63. Loans for tradesmen in Jerusalem, 1940, CZA, S18/34; loans for kiosk owners in Tel Aviv, 1940, ibid.

64. Correspondence concerns the unpaid loan of Isaak Fiegin, March 24, 1938, CZA, L51/764; letter from the Jewish Agency seeking the whereabouts of Ingrid Kahanman who failed to repay her business loan, December 7, 1938, ibid., S7/805. One of her acquaintances reported her new address. 
activity was substantial. The committees that handled the loan applications on behalf of the Jewish national and banking institutions based their decisions on economic data, but also on social perceptions as to who and what sort of economic activity ought to be encouraged. In this way, the committees and the negotiations they occasioned turned into shapers of communal identity. Authorizing a loan for a venture and certifying business activity became markers of normative business perceptions. As it was these loan funds to which women entrepreneurs addressed their applications for financial support, the mechanisms of granting business loans make it possible to uncover three perspectives that are relevant to this article's arguments. First, the reactions of the members of the loan committees to requests by women shed light on the extent to which contemporary perceptions of gender impacted allocations of resources, and thereby the business scene as a whole. Second, from another perspective, these reactions reaffirm the role of the family in the credit system and of women in particular. Finally, they demonstrate the weight given in business matters to Zionism and nation building.

Gender perceptions concerning women's social duties and personal traits among committee member surfaced in inner correspondence and in their decisions on loan allocation. Members of the loan and licensing committees repeatedly emphasized the transgression of the women, mainly by doubting their credibility and capacity to run a business. "The said business was established forty years ago by the late Mr. Rabinowitz," replied a committee to one petition. "In recent years we lost all faith in the right of that business to exist. Granted, however, that the owner was an old customer of ours and an honorable person, we did not want to claim our money back at once, as that would have caused the shutdown of the business. Mr. Rabinowitz died two years ago and the business passed on to his wife who, apparently, is unable to run it." 65 In contrast to the respect, trust, and business tolerance expressed by the committee's letter toward the deceased merchant, his widow was dismissed outright. Depicted as incapable, she was held personally responsible for the unfortunate fate of a business that was considered a failure from the start. It is no wonder, then, that such a perception of women's managerial incompetence and inadequate comprehension of the complex mechanisms of the financial market in many cases induced the committees to forward the women applicants for business loans to wage-earning jobs. ${ }^{66}$

65. The Anglo-Palestine Bank to the Jewish Agency loans committee concerning the loan request of Haya Rabinowitz, February 7, 1937, CZA, L51/704.

66. Johnson, "New Approaches to Understanding the Gendered Economy." 
To emphasize the mismatch between women and business, the committees also resorted to distorting the language women employed in their requests. In their application letters, women often presented themselves as "abandoned" or "alone." 67 The terms were used as semantic signifiers to stress the absence of a male provider as a push factor forcing them to establish a business. In a sense this was reminiscent of the "Femme Sole" in the pre-modern British legal system, which denoted women business owners as "uncovered" by their husbands and thus entitled to trade on their own. ${ }^{68}$ In their internal correspondence regarding women who had no male providers, the committees' members replaced these terms, using "miserable" and "desolate" instead. ${ }^{69}$ The terminology expanded the loneness argument by adding a mental dimension, pointing to the irrationality of the women who wished to engage in business. In this way, the appropriateness of the quest for a loan was challenged and rhetorically delegitimized.

The stigmatization of women's deviance from the norm and transgression into the business arena was clearly influential. In one case, a committee discussed a request for a loan by a professional woman so she could provide for her family. The initial decision was to reject the petition, but after the woman appealed, the committee adopted a proposal by one of its members to allow her the requested sum not as a loan, but as charity. ${ }^{70}$ At the same meeting, the committee discussed a loan repayment failure by a man; not only did it decide to forgive his delays, but it also accepted his request for additional guarantors. The argument that a loan for a woman was akin to charity was therefore a euphemism for what was perceived as women's unsuitability and incapacity to perform adequately in the business arena, and thus for relegating them to the category of philanthropy. A corollary of that approach was to glorify loan-giving to women as a distinct and commendable public effort. When one woman debtor of the Manufacturers' Loan Fund fell behind in repayments, the fund's manager

67. Sara Fisch to the municipal general secretary, Yehuda Nedivi, concerning her business license, January 11, 1940, MATEJ, 04-3643.

68. Phillips, “A Customary Privilege?” This status enabled women to trade and act as independent legal entities, not represented by any familial male figure. However, as Phillips and other historians noted, the main reason for introducing this procedure was a national concern for economic stability rather than concern for women's economic independence.

69. Report by a municipality inspector to Yehuda Nedivi, the municipal general secretary, concerning a business license, MATEJ, January 11, 1948, 04-3643.

70. Minutes of the meeting of the artisans' loan fund committee, June 30, 1938, CZA, S18/105. 
reproached her: "Anyone who receives a special favor must pay back the money in order."71

The prominence of gender perceptions was one aspect that characterized the loan representatives' decision making. Another prominent aspect was the affinity made between women who wished to enter business and their families. The difficulty to ensure loan payback, and the grounding of the entire communal loan system on honor and trust, made the family the main provider of guarantees. Men could rely not only on the family but also on business networks. Women's networks, however, were anchored in familial ties and less associated with work and occupation. This was why husbands, fathers, and sons were prominent among the women's loan guarantors. Moreover, it dictated the deep involvement of family members in establishing and the daily running of the women's business. Evidently the association between women's business and family enhanced the women's reputation in the eyes of the members of the loan committees. This is typical in nation and state building processes in which prior economic structures undergo institutionalization and reordering of the preference for financial credit. In such situations, the family, as a backing economic unit for those whose access to credit is narrow, becomes most important. The financial stability of the family, the assets it owns, and its close social connections may have an enormous impact on the capacity of an individual—and a woman in particularto raise credit. ${ }^{72}$ Thus, the documentation discloses recurring references to women's affiliation with their husbands or fathers as purporting to weaken women's affiliation with the business world. The registries of loan petitions and loan guarantors, and the committees' correspondence, routinely added to the women's names such appellations as "the deceased's wife," "wife of the officer," "wife of the pharmacist," and so on. ${ }^{73}$ Whereas women stressed their family affiliations to mobilize legitimacy for entry into business, the committees, in contrast, used the explication of familial links to strengthen them. This weakened women's legitimacy to act as agents worthy of owning an independent business. When a woman's request for a loan was granted, the reason often stated was the joblessness of the husbandresulting from immigration or economic ruin-or the absence of a breadwinning spouse following disease, disability, or death. For example, in the lists of approved loan applications, a note was added

71. The Department of Trade's loan fund to Mussia Diamant, December 15, 1940, CZA, S18/217.

72. Tenenbaum, Credit to Their Community; Morawska, "Insecure Prosperity."

73. Loan applications, June 15, 1938, CZA, S1/2071; January 6, 1947, ibid., S21/221; June 19, 1938, ibid., S18/213. 
next to the names of several women recipients indicating that the reason for approval was their husbands' recruitment to military service. Similarly, the proper business pedigree of the woman applicant was clearly specified on the application forms: "She is one of the successors of Joshua Berman, of the acclaimed firm of J. and A. Berman"74_the emphasis being on family affiliation and on forced circumstances. And in the same vein, when a male applicant noted a woman as his loan guarantor, a handwritten note was added beside her name stating she was a "widowed woman"—and the loan request was rejected. The absence of a male provider clearly inspired the portrayal of the woman as lacking the economic viability needed to ensure repayment.

However, gender perceptions, as well as family considerations, were secondary in decision-making processes concerning business loans. The most prominent consideration was the promotion and buttressing of nation building and economic independence. The political hegemony since the mid-1930s was in the hands of Mapai, the leading political party of the labor movement and the main shaper of the Zionist strategies of settlement, conflict, and community building. Mapai's pragmatism trumpeted the supremacy of nation over class, and led to labor's cooperation with the weak liberal organizations in the Yishuv and with the capitalist sector they represented. Private capital and the employers in the private sector were perceived by many in both the labor and liberal camps as prime motors of economic growth.

The diversified institutions and associations that were involved in the foundation of business loan funds under the umbrella of the Jewish Agency point to the level of commitment and recruitment of diverse politically affiliated bodies and social strata to nation building. Middle-class press and sectorial bulletins expressed these notions frequently: "Great is the role of the Jewish merchant in building the country. With his initiative and talent all the materials have been brought over, with which wastelands were made to bloom and cities built."75

The public debate over the relationship among women's work, the Zionist project, and social mores in Yishuv society clearly influenced the decision making of the loan committees and their expectations regarding the outcomes of authorizing loans. In 1943, a report on the development of home industries, aimed mainly at women, stated: "Searching for new branches of productive work is an essential and urgent economic priority in light of the growing distress in the Yishuv

74. List of the loans for Jerusalem merchants, no date, CZA, S1/1848.

75. Hatzofeh (daily newspaper of the Mizrahi movement), April 4, 1943. 
and the rising number of needy immigrants."76 Addressing the topic a year later, an article in a liberal newspaper was doubtful as to the results of women's public and national involvement: "We set out for the main road on equal terms, and it was helped by the fact that in our new homeland women stood everywhere alongside men: in work, manufacture, agriculture and industry. ... The question-whether we crossed all the boundaries in this radical erasure of distinctions, thereby causing harm to the family and to the Yishuv's future-will need to be considered seriously and conclusions drawn."77

Despite the ambiguous approach of this writer, the promotion of national aspirations was accepted by loan committee delegates as a significant credential of women entrepreneurs. Emphasis was put not on mere affiliation with Zionist ideas but also on Zionist activism, as demonstrated in the following letter of recommendation from WIZO concerning a woman seeking to establish an embroidery enterprise: "She emigrated to Tel Aviv from Vienna, and she wishes to establish in the land of Israel a new venture-a tapestry industry destined for export to English-speaking countries. Mrs. Modlinger makes an excellent impression as a serious and responsible woman. She is a veteran Zionist—and was very active in the Zionist movement."78 Another letter makes a clear distinction between Zionist consciousness and Zionist activism: "I have the honor of knowing her for several years. She is a conscious Zionist for many years. In coming to Palestine she puts her Zionism into practice.”79

Interestingly enough, active contribution to nation building did not necessarily override gender perceptions. The Home Industry Project is an example of the amalgamation of national and gender considerations. One of the definitions of a home industry was that it could not compete with production industries. WIZO and the Jewish Agency therefore decided that providing support would be conditional upon the enterprise being a temporary aid to the familial household economy and carried out only at home. This entailed a paradox. Although, as stated in the press, economic productivity was a major Zionist and institutional concern, the definition of productivity aimed at women's enterprises confined them to small-scale entrepreneurship, impeding their chances of expanding.

76. Report on the development of home industries, 1943, no specified date, CZA, S1/2036.

77. Haboker (daily newspaper of the liberal General Zionists), April 27, 1944.

78. Zionist Women's Association to the loan fund's committee, May 2, 1939, CZA, S9/1457.

79. The Jewish Agency to the German department in the matter of Aliza Strashnov, October 11, 1939, CZA, S7/206; Engineer Bien to the German Department in the matter of a loan to Ester Rivies, ibid., S7/2121, February 6, 1942. 
Another impediment to women's business activity arose from moral concerns relating to national boundaries. This was especially relevant to women who operated businesses in the hosting sector. In a telling example, a municipal clerk was trying to help a woman obtain a proper license for a guesthouse she owned, and explained to his colleague the bureaucratic difficulties she had to tackle: "She had to-what? Continue work without a license?" And to drive home his point, he added: "To live in sin?" 80 The sin, the guesthouse, and the woman owner were in this case closely entangled. This was particularly true in the context of nation building taking place in a bi-ethnic society, in which the moral perceptions of women's activity in the public space were a national issue, hardly a private business matter.

A wide range of institutions therefore took part in inaugurating funds that catered loans for establishing businesses. However, the similar patterns that arose in the responses of representatives of those loan committees to women's attempts to enter entrepreneurship indicate that gender perceptions with respect to the role and place of women were common to all strata of the middle classes. These concepts, in regard to the relations between gender and family and to women's roles in nation building, shaped women's opportunities to enter entrepreneurship.

\section{Conclusions}

This article focused on the entry problems of Yishuv women to business in the context of the Zionist nation-building community of Jewish immigrants living under British colonial rule and engaged in national conflict between Arabs and Jews. However, the case sheds light on various aspects in the literature on credit, gender, and entrepreneurship. First, although research into women's contributions to national struggles usually focuses on their participation in political movements, military activities, and the economy of the home, we argue for the need to focus on women's entrepreneurship in a state-building society, and on women's entry thresholds to entrepreneurship in particular. The importance accorded by the Zionist movement and its institutions to the building of a prosperous economy and to absorbing of Jewish immigrants in the Palestine economy offered middle-class women the opportunity to enter small business despite the fact that such activity was perceived as deviating from their class norms and social mores. Our findings demonstrate that gender perceptions often

80. Municipal general secretary Yehuda Nedivi to the licensing department, June 5, 1942, MATEJ, 04-2314. 
overshadowed criteria of economic efficiency or rationality. Both the women who sought loans or business licenses and the committee members who deliberated their requests presented arguments relating to gender. Some of these arguments drew on middle-class cultural perceptions as to women's familial duties, whereas others referred to gender roles in the nation-building project. Evidently the relational mix of gender and nation building was much more powerful in affecting women's entry to business than a mere male-dominated cultural conceptualizations of the roles of women. This mix "politicized" the business threshold.

Second, the analysis of women's business entrepreneurship in the Yishuv reaffirms the strong affinity to home economics. Serving as a driving force, many women became entrepreneurs or entered business following familial hardships and malfunctioning caused by the arduous immigration to Palestine. Home economics supplied an economic context as well, as women founded businesses primarily in hospitality, catering, textiles, and embroidery, mostly associated with the skills acquired by women for the purpose of housekeeping. Finally, family members were found to be deeply engaged in the regulation and provision of guarantees and in raising loans for the establishment of women's businesses. These linkages among home economics, family status, and women's ownership of businesses blur the distinctions between home and business. At the same time, women in the Yishuv who wished to gain legitimacy for establishing a business did not emphasize only their entrepreneurial drive, but also stressed familial hardships or presented their wishes in accordance with the nation-building aspirations of the community.

The fact that many women were pushed to start businesses because of dire economic needs related to immigration or loss of husbands calls for reconsideration of the perception of entrepreneurship. The latter is etymologically related to "the one who undertakes" and thus allows for a variety of entrepreneurial types and motivations. In identifying entrepreneurship with innovation, the historiography has given overdue weight to a gendered perception of an otherwise much richer phenomenon and social practice. As demonstrated here, a drive for innovation was only one among many reasons that women turned to entrepreneurship. Moreover, innovation was even less relevant, and even socially perceived an illegitimate venue, for middleclass women whose social and cultural roles had been widely defined as wives and mothers. As is demonstrated here, economic necessities provided women with a variety of justifications for obtaining consent to enter an entrepreneurial activity. This is why women's small-scale ventures, both in traditional crafts and in services, may be an interesting line of research to follow. 
Moreover, credit, too, emerges here as a multifaceted phenomenon. The search for financial credit and the entailed negotiations between loan petitioners and loan givers seem socially formative: the loan providers selected the receivers partly according to their cultural perceptions of who was fit and legitimate for entrepreneurial activity. At the same time, they allowed the women applicants to present themselves as demanding access to wider economic activities. In these ways, credit is revealed here as a social and economic window of opportunity, in particular for groups who lacked financial and social capital of their own, and in dynamic contexts such as nation building.

Third, unlike other immigrant communities where national identity, based on countries of origin, helped to preserve a sense of collective identity in the hosting country and provided supporting networks for business activity, ${ }^{81}$ for the Jewish community in Palestine Zionism was a formative factor in entrepreneurial and business activity. Establishing a business was looked at and legitimatized mainly through its potential contribution to the promotion of the collective good-largely defined as the gaining of political sovereignty. Moreover, Zionism and the pursuit of state building were incorporated into all levels of trade and economic discussions down to loans of individual small firms. It was here that the dual relationship between women's business activity and nation building was exposed. Women adhered to national capitalism as a channel through which they could contribute to the advancement of the political aspirations of the community, while at the same time expanding their presence and legitimacy in the economic public sphere. Harnessing their business to nation building by promoting literacy in Hebrew, developing local manufacturing or creating jobs for Jews only, women also mobilized nation building for the promotion of their business activities. Herein lay the complex relations that contributed to the gendering of the business world in times of nation-building processes.

\section{Bibliography of Works Cited}

Sources in Hebrew are marked [H].

\section{Books}

Aretxaga, Begona. Shattering Silence: Women, Nationalism and Political Subjectivity in Northern Ireland. Princeton, NJ: Princeton University Press, 1998.

Bernstein, Deborah S. (ed.). Pioneers and Homemakers: Jewish Women in PreState Israel. Albany, NY: State University of New York Press, 1992.

81. Godley, Jewish Immigrant Entrepreneurship. 
Davidoff, Leonore, and Hall, Catherine. Family Fortunes: Men and Women of the English Middle Class, 1780-1850. London: Routledge, 1987.

Eilam, Yigal. The Jewish Agency: The First Years. Jerusalem Eded : Zionist Library,1990. [H]

Glenn, Susan A. Daughters of the Shtetl: Life and Labor in the Immigrant Generation. Ithaca, NY: Cornell University Press, 1991.

Gluzman, Michael. The Zionist Body: Nationalism, Gender and Sexuality in Modern Hebrew Literature. Tel Aviv: Hakibutz Hameuchad, 2007. [H]

Godley, Andrew. Jewish Immigrant Entrepreneurship in New York and London 1880-1914: Enterprise and Culture. Houndmills, Basingstoke, UK: Palgrave, 2001.

Halperin, Liora. Babel in Zion: The Politics of Language Diversity in Jewish Palestine 1920-1948. New Haven, CT: Yale University Press, 2015.

Herzl, Theodor. Altneuland [1902]. Tel Aviv: Babel, 2008. [H]

Horowitz, Dan, and Moshe Lissak. Trouble in Utopia: The Overburdened Polity of Israel. Albany, NY: State University of New York Press, 1989.

Hyman, Paula. Gender and Assimilation in Modern Jewish History: The Roles and Representation of Women. Seattle: University of Washington Press, 1995.

Ingalls Lewis, Susan. Unexceptional Women: Female Proprietors in Mid-Nineteenth-Century Albany, New York, 1830-1885. Columbus: Ohio State University Press, 2009.

Jayawardena, Kumari. Feminism and Nationalism in the Third World. London: Zed Books, 1986.

Kaplan, Marion. A. The Making of the Jewish Middle Class: Women, Family, and Identity in Imperial Germany. New York: Oxford University Press, 1991.

Kocka, Jurgen. Industrial Culture and Bourgeois Society: Business, Labor, and Bureaucracy in Modern Germany. New York: Berghahn Books, 1999.

Kwolek-Folland, Angel. Incorporating Women: A History of Women and Business in the United States. New York: Twayne Publishers, 2002.

Lemire, Beverly, Ruth Pearson, and Gail Campbell (eds.). Women and Credit: Researching the Past, Refiguring the Future. Oxford: Berg, 2002.

Metzer, Jacob. The Divided Economy of Mandatory Palestine. Cambridge: Cambridge University Press, 1998.

Moghadan, Valentine M. (ed.). Gender and National Identity: Women and Politics in Muslim Societies. London: Zed Books; Karachi: Oxford University Press, 1994.

Nairn, Tom. The Breakup of Britain. London: Verso, 1977.

Peli, Bracha. Life of Bracha. Givatayim, Israel: Massada, 1984. [H]

Penslar, Derek J. Shylock's Children: Economic and Jewish Identity in Modern Europe. Berkeley: University of California Press, 2001.

Phillips, Nicola Jane. Women in Business, 1700-1850. London: Boydell \& Brewer Ltd, 2006.

Reagin, Nancy. Sweeping the German Nation: Domesticity and National Identity in Germany, 1870-1945. Cambridge and New York: Cambridge University Press, 2006. 
Ryan, Mary P. Cradle of the Middle Class: The Family in Oneida County, New York, 1790-1865. Cambridge: Cambridge University Press, 1983.

Silva, Neluka. The Gendered Nation: Contemporary Writings from South Asia. Thousand Oaks, CA: Sage, 2004.

Simonton, Deborah. A History of European Women's Work, 1700 to the Present. London: Psychology Press, 1998.

Sparks, Edith. Capital Intentions: Female Proprietors in San Francisco, 18501920. Chapel Hill: University of North Carolina Press, 2006.

Tenenbaum, Shelly. Credit to Their Community: Jewish Loan Societies in the United States, 1880-1945. Detroit: Wayne State University Press, 1993.

Yuval-Davis, Nira, and Floya Anthias (eds.). Woman, Nation, State. New York: St. Martin's Press, 1989.

Zborowski, Mark, and Elizabeth Herzog. Life Is with People. New York: International Universities Press, 1952.

\section{Articles and Book Chapters}

Abdo, Nahla. "Nationalism and Feminism: Palestinian Women and IntifadaNo Going Back?” In Gender and National Identity: Women and Politics in Muslim Societies, edited by Valentine Moghadan, 148-169. London: Zed Books; Karachi: Oxford University Press, 1994.

Alroy, Gur. "The Labor Battalion of the Craftsmen: A Story of a Failed Athos." Iyunim Betkumat Israel 13 (2003): 255-275. [H]

Beachy, Robert. "Business Was a Family Affair: Women of Commerce in Central Europe, 1650-1880." Histoire Sociale 34, no. 68 (2001): 307-330.

Bernstein, Deborah. "The Plough Woman Who Cried into the Pots: The Position of Women in the Labor Force in the Pre-State Israeli Society," Jewish Social Studies 45, no. 1(1983): 43-56.

Brichni-Schimmer, Inna. "The Professions of Immigrants from Germany." Hameshek Hashitufi 4 (1936): 22-23. [H]

Brouwer, Matia T. "Schumpeter and Knight on Entrepreneurship and Economic Development." Journal of Evolutionary Economics 12 (2002): 83-105.

Burman, Ricki. "The Jewish Woman as Breadwinner: The Changing Value of Women's Work in a Manchester Immigrant Community." Oral History 10 (1982): 27-39.

Cuevas, J. Guzman. "Towards a Taxonomy of Entrepreneurial Theories." International Small Business Journal 12 (1994): 77-88.

Davidoff, Leonore. "Gender and the 'Great Divide': Public and Private in British Gender History.” Journal of Women’s History 15 (2003):11-27.

Delaney, Carol L. "Father State, Motherland, and the Birth of Modern Turkey." In Naturalizing Power: Essays in Feminist Cultural Analysis, edited by Sylvia Yanagisako and Carol L. Delaney, 177-199. New York: Psychology Press, 1995.

De Vries, David. "National Construction of Occupational Identity: Jewish Clerks in British-Ruled Palestine." Comparative Studies in Society and History 39 (1997): 373-400.

Ericsson, Tom. "Women, Family, and Small Business in Late Nineteenth Century Sweden." The History of the Family 6, no. 2 (2001): 225-239. 
Flieschman, Ellen L. “The Other 'Awakening': The Emergence of Women's Movement in the Modern Middle East." In A Social History of Women and Gender in the Middle East, edited by Margaret L. Meriwether and Judith E. Tucker, 89-139. Boulder, CO: Westview Press, 1999.

Gamber, Wendy. "A Gendered Enterprise: Placing Nineteenth Century Businesswomen in History.” Business History Review 72 (1998): 188-219.

— . "Gendered Concern: Thoughts on the History of Business and the History of Women." Business and Economy History 23, no. 1 (1994):129-140.

—. "A Precarious Independence: Milliners and Dressmakers in Boston, 1860-1890." Journal of Women's History 4, no. 1 (1992): 60-88.

Green, Nancy L. "Gender and Jobs in the Jewish Community: Europe at the Turn of the Twentieth Century." Jewish Social Studies 8, no. 2 (2002): 39-60.

Gross, Nachum, and Jacob Metzer. "Public Finance in the Jewish Economy in Interwar Palestine." Research in Economic History 3 (1978): 87-159.

Hausen, Karin. "Family and Role-Division: The Polarisation of Sexual Stereotypes in the Nineteenth Century-An Aspect of the Dissociation of Work and Family Life." In The German Family, edited by R. Evans and W. Lee, 51-83. London: Croom Helm, 1981.

Hegland, Mary E. "Gender and Religion in the Middle East and South Asia: Women's Voices Rising," In A Social History of Women and Gender in the Modern Middle East, edited by Margaret L. Meriwether and Judith E. Tucker, 177-212. Boulder, CO: Westview Press, 1999.

Joffe, Natalie, F. "The Dynamics of Benefice among East European Jews." Social Forces 27, no. 3 (1949): 238-247.

Johnson, Margaret A. "New Approaches to Understanding the Gendered Economy: Self-Employed Women, Microcredit, and the Nonprofit Sector." In Immigrant and Minority Entrepreneurship: the Continuous Rebirth of American Communities, edited by John Sibley Butler and George Kozmetsky, 149-170, Westport, CT: Greenwood, 2004.

Karlinsky, Nahum. "Private Credit Cooperatives in Mandatory Palestine." In Economy and Society in Mandatory Palestine, 1918-1948, edited by Avi Bareli and Nahum Karlinsky, 239-285. Sede Boqer, Israel: The Ben Gurion Research Center, 2003. [H]

Kerber, Linda K. "Separate Spheres, Female Worlds, Woman's Place: The Rhetoric of Women's History.” The Journal of American History 75, no. 1(1988): 9-39.

Kimmerling, Baruch. "State Building, State Autonomy and the Identity of Society: The Case of the Israeli State." Journal of Historical Sociology 6 (1993): 396-429.

Landes, Joan B. "Further Thoughts on the Public/Private Distinction." Journal of Women's History 15, no. 2 (2003): 28-39.

Lestchinsky, Jacob. "Economic Aspects of Jewish community Organization in Independent Poland.” Jewish Social Studies 9 (1947): 319-338.

Maleckova, Jitka. "Where Are Women in National Histories?" In The Contested Nation Ethnicity, Class, Religion and Gender in National Histories, edited by Stefan Berger and Chris Lorenz, 171-199. Basingstoke, UK: Palgrave Macmillan, 2008. 
Mayer, Tamar. "Gender Ironies of Nationalism-Setting the Stage." In Gender Ironies of Nationalism-Sexing the Nation, edited by Tamar Mayer, 1-19. London: Psychology Press, 2000.

Metzer, Jacob. "Economic Structure and National Goals—Jewish National Home in Interwar Palestine.” The Journal of Economic History 38 (1978):101-119.

Muldrew, Craig. "Interpreting the Market: The Ethics of Credit and Community Relations in Early Modern England.” Social History 18 (1993): 163-183.

Nadan, Amos. "The Competitive Advantage of Moneylenders over Banks in Rural Palestine." Journal of the Economic and Social History of the Orient 48 (2005): 1-39.

Nagel, Joane. "Masculinity and Nationalism: Gender and Sexuality in the Making of Nations." Ethnic and Racial Studies 21 (1998): 242-270.

Nenadic, Stena. "The Social Shaping of Business Behavior in the NineteenthCentury Women Garment Trades.” Journal of Social History 31 (1998): 626-647.

Peiss, Kathy. "Vital Industry and Women's Ventures: Conceptualizing Gender in Twentieth Century Business History." Business History Review 72 (1998): 219-241.

Phillips, Nicola J. "A Customary Privilege? Common Law, Borough Custom and the Femme Sole Trader." In Women in Business, 1700-1850, edited by Nicola J. Phillips, 48-68. London: Boydell \& Brewer Ltd, 2006.

Pfefferman, Talia. "Separate Spheres, Intertwined Spheres: Home, Work, and Family among Jewish Women Business Owners in the Yishuv.” The Journal of Israeli History 32 (2013): 7-28.

Reagin, Nancy. "The Imagined Hausfrau: National Identity, Domesticity, and Colonialism in Imperial Germany." The Journal of Modern History 73, no. 1 (2001): 54-86.

Rutterford, Janette and Josephine Maltby. "The Widow, the Clergyman and the Reckless: Women Investors in England, 1830-1914.” Feminist Economics 12 (2006): 111-138.

Scott, Joan W. "Comment: Conceptualizing Gender in American Business History," Business History Review 72, no. 2 (1998): 242-249.

Stern, Bat Sheva M. '“He Walked Through the Fields,' but What Did She Do? The 'Hebrew Woman' in Her Own Eyes and in the Eyes of Her Contemporaries." Journal of Israeli History 30, no. 2 (2011): 161-187.

Sharpe, Pamela. "Gender in the Economy: Female Merchants and Family: Business in the British Isles, 1600-1850," Histoire Sociale, 34 (2001): 283-306.

Taschereau, Sylvie. "Jewish Loan Societies in Montreal, 1911-1945." Urban History Review 33, no. 2 (2005): 3-16.

Tenenbaum, Shelly. "Culture and Context: The Emergence of Hebrew Free Loan Societies in the United States," Social Science History 13, no. 3 (1989): 211-236.

Turnowsky-Pinner, Margaret. "Jewish Women of Palestine in Trades and Professions." Tel Aviv: WIZO Instruction and Information Centre, 1948.

Vickery, Amanda. "Golden Age to Separate Spheres? A Review of the Categories and Chronology of English Women's History." The Historical Journal 36, no. 2 (1993): 383-414. 
Walsh, Margaret. "Gendered Endeavors: Women and the Reshaping of Business Culture." Women's History Review 14 (2005): 181-202.

Wood, Kirsten E. "Broken Reeds and Competent Farmers: Slaveholding Widows in the Southeastern United States, 1783-1861." Journal of Women's History 13 (2001): 34-57.

Yohn, Susan M. "Crippled Capitalists: The Inscription of Economic Dependence and the Challenge of Female Entrepreneurship in Nineteenth-Century America." Feminist Economics 12 (2006): 85-109.

\section{Archives}

CZA: Central Zionist Archive, Jerusalem.

MATEJ: Municipality of Tel Aviv-Jaffa Archive

\section{Contemporary Newspapers}

Davar (H)

Haboker $(\mathrm{H})$

Hatzofeh (H) 